\title{
FIRST RECORD OF CLEMMUS TROGLODYTES (COLEOPTERA: COCCINELLOIDEA, ANAMORPHIDAE) FOR THE FAUNA OF RUSSIA
}

\author{
Wioletta Tomaszewska ${ }^{1}$, Leonid V. Egorov ${ }^{2,3}$, Alexander B. Ruchin ${ }^{3}$, Dmitry V. Vlasov ${ }^{4}$ \\ ${ }^{1}$ Museum and Institute of Zoology, Polish Academy of Sciences, Poland \\ e-mail:wiolkat@miiz.waw.pl \\ ${ }^{2}$ State Nature Reserve «Prisursky», Russia \\ e-mail:platyscelis@mail.ru \\ ${ }^{3}$ Joint Directorate of the Mordovia State Nature Reserve and National Park «Smolny», Russia \\ e-mail: sasharuchin@rambler.ru \\ ${ }^{4}$ Yaroslavl State Historical and Árchitectural Museum-Reserve, Russia \\ e-mail:mitrich-koroed@mail.ru
}

Received: 10.02.2018

\begin{abstract}
During field investigations in 2017, Clemmus troglodytes was found in the Mordovia State Nature Reserve (Republic of Mordovia, Russia). Earlier, C. troglodytes was collected in Yaroslavl City (Yaroslavl region, Russia). In this paper we are reporting for the first time both genus Clemmus and species C. troglodytes for the fauna of Russia. These records of the species in Russia extend remarkably its range to the north and east.
\end{abstract}

Key words: Coleoptera, Coccinelloidea, handsome fungus beetles, Anamorphidae, new record, Mordovia, Mordovia State Nature Reserve, Yaroslavl region, Russia

The world fauna of the handsome fungus beetles in a broad sense (Tomaszewska, 2000, 2010) contains over 1800 validly described species and subspecies. They belong to 130 genera divided into 12 subfamilies (Tomaszewska, 2010). For the fauna of Russia there are known 24 species from 11 genera (Tomaszewska, 2007; Kovalenko \& Nikitsky, 2013).

Recent changes in cucujiform beetle classification (Robertson et al., 2015) resulted among others in separation of Endomychidae sensu stricto, and raising Anamorphinae, Mycetaeinae, and Eupsilobiinae as independent families. So now, the family Anamorphidae in the territory of Russia includes 4 species from 3 genera - Dexialia minor (Chûjô, 1941) from the Far East, two predominantly European species - Mychothenus caspicus (Reitter, 1883) and M. minutus (Frivaldszky, 1877), while Symbiotes gibberosus (Lucas, 1846) has been reported from Europe, North Africa, the Canary Islands and North America (Tomaszewska, 2007).

During the study of the Coleoptera composition in the Mordovia State Nature Reserve using the window trap method (Egorov \& Semishin, 2016) in 2017, we have collected a species from the genus Clemmus Hampe, 1850 which is considered as new for the fauna of Russia. Earlier, the same species was also found by D.V. Vlasov in Yaroslavl City, although until now this specimen had not been determined.
Clemmus is represented by four species in the world: C. abbreviatus (Reitter, 1889) from Japan, C. humeralis (Lea, 1921) from Australia, C. minor (Crotch, 1783) from the USA and $C$. troglodytes Hampe, 1850 from Europe (Shockley et al., 2009). The specimens collected in the Mordovia State Nature Reserve belong to the European species $C$. troglodytes (Fig. 1). Until now, the eastern border of its range was considered being the Ukrainian Carpathians (Mateleshko, 2009). Thus, our new records are the most northern and eastern within the species' range. The studied material is stored in the collection of the Museum \& Institute of Zoology, Polish Academy of Sciences (Warsaw, Poland) (MIZ); Zoological Institute of the Russian Academy of Sciences (St. Petersburg, Russia) (ZIN) and in the private collection of Dmitry V. Vlasov (Yaroslavl, Russia).

\section{Clemmus troglodytes Hampe, 1850}

Material. Russia: Mordovia, Temnikov distr., $11 \mathrm{~km}$ NNW of Temnikov, 54 $43^{\prime} 56^{\prime \prime} \mathrm{N}$, $43^{\circ} 09^{\prime} 29^{\prime \prime} \mathrm{E}$, Mordovia State Nature Reserve, quarter 436, 29.VI-13.VII.2017, mixed forest, window trap 1 ex., leg. L.V. Egorov, G.B. Semishin (deposited in ZIN); same locality, 13-27.VII.2017, mixed forest, window trap 1 ex., leg. L.V. Egorov, G.B. Semishin (deposited in MIZ). Yaroslavl region, Yaroslavl, central part, $57^{\circ} 38^{\prime} 04^{\prime \prime} \mathrm{N}, 39^{\circ} 53^{\prime} 03^{\prime \prime} \mathrm{E}$, 
7.II.1998, in the hollow of a tree (Tilia cordata Mill.), 1 dead ex., leg. D.V. Vlasov (private collection of D.V. Vlasov).

Distribution. Austria, Bulgaria, Croatia, Czech Republic, Hungary, Italy, Romania, Slovakia, Slovenia (Tomaszewska, 2007), Ukraine (Mateleshko, 2009), Russia (Central European Territory) and the Netherlands (Heijerman \& Noordijk, 2017).

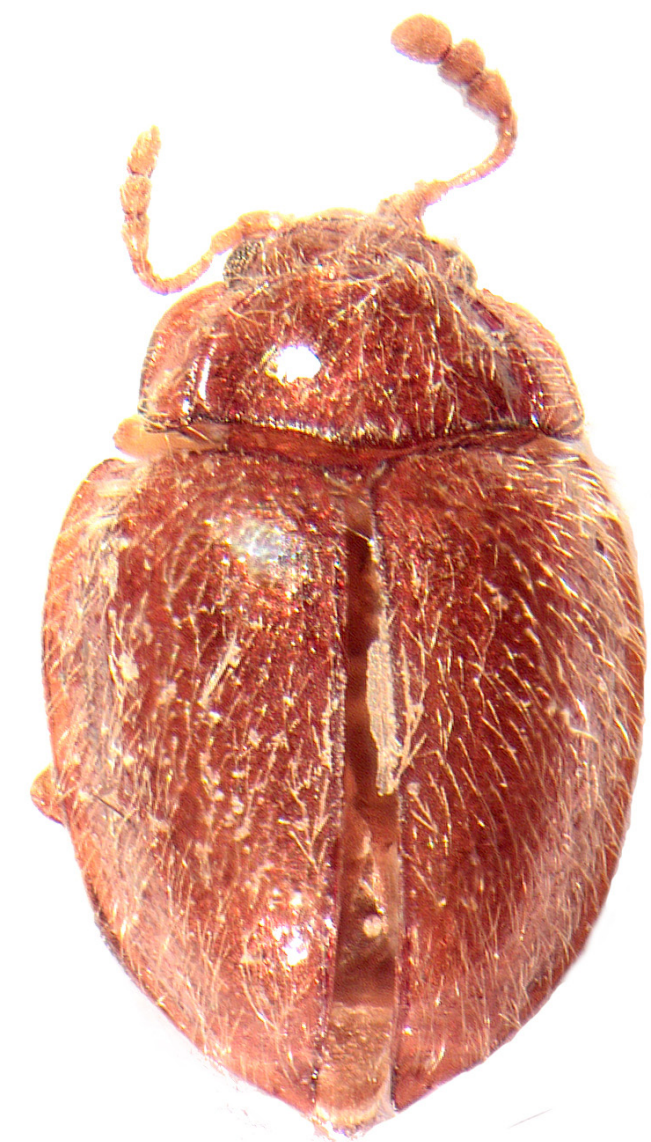

Fig. 1. Clemmus troglodytes (photo: Wioletta Tomaszewska).
Bionomics. In the Mordovia State Nature Reserve, the species was collected in linden-aspen (Tilia cordata + Populus tremula L.) forest with Carex pilosa Scop. dominance and participation of ferns in herb cover (Fig. 2). Besides Tilia cordata and Populus tremula, the forest stand consists of single trees of Quercus robur L., Picea abies (L.) H. Karst., Betula pendula Roth. The understory layer is presented by Ulmus glabra Huds., U. laevis Pall., Acer platanoides L. The following shrubs are common in the plant community: Euonymus verrucosus Scop., Lonicera xylosteum L. and Corylus avellana L. Besides dominating Carex pilosa, the herb layer includes Dryopteris filix-mas (L.) Schott, D. carthusiana (Vill.) H.P. Fuchs, Athyrium filix-femina (L.) Roth, Aegopodium podagraria L., Milium effusum L., Galium odoratum (L.) Scop., Glechoma hederacea L., Asarum europaeum L., rarely-Mercurialis perennis L., Pulmonaria obscura Dumort., Stellaria holostea L., Anemone ranunculoides L., Lathyrus vernus (L.) Bernh., Festuca gigantea (L.) Vill. (Chugunov et al., 2017). The zonal type of vegetation in Mordovia is coniferous and broadleaf forests situated in the Central Russian Subprovince of the East-European Province of the European Broadleaf Forest Region (Gribova et al., 1980). Together with this Clemmus species, also Leiestes seminiger (Gyllenhal, 1808) and Mycetina cruciata (Schaller, 1783) of Endomychidae sensu stricto have been collected here.

In Yaroslavl, a dead specimen was found in the hollow of a felled linden (Tilia cordata) within the urban plantings of the city centre.

Earlier, in Europe the species was reported found in oak (Quercus robur) forests under the bark of oaks (Roubal, 1936).
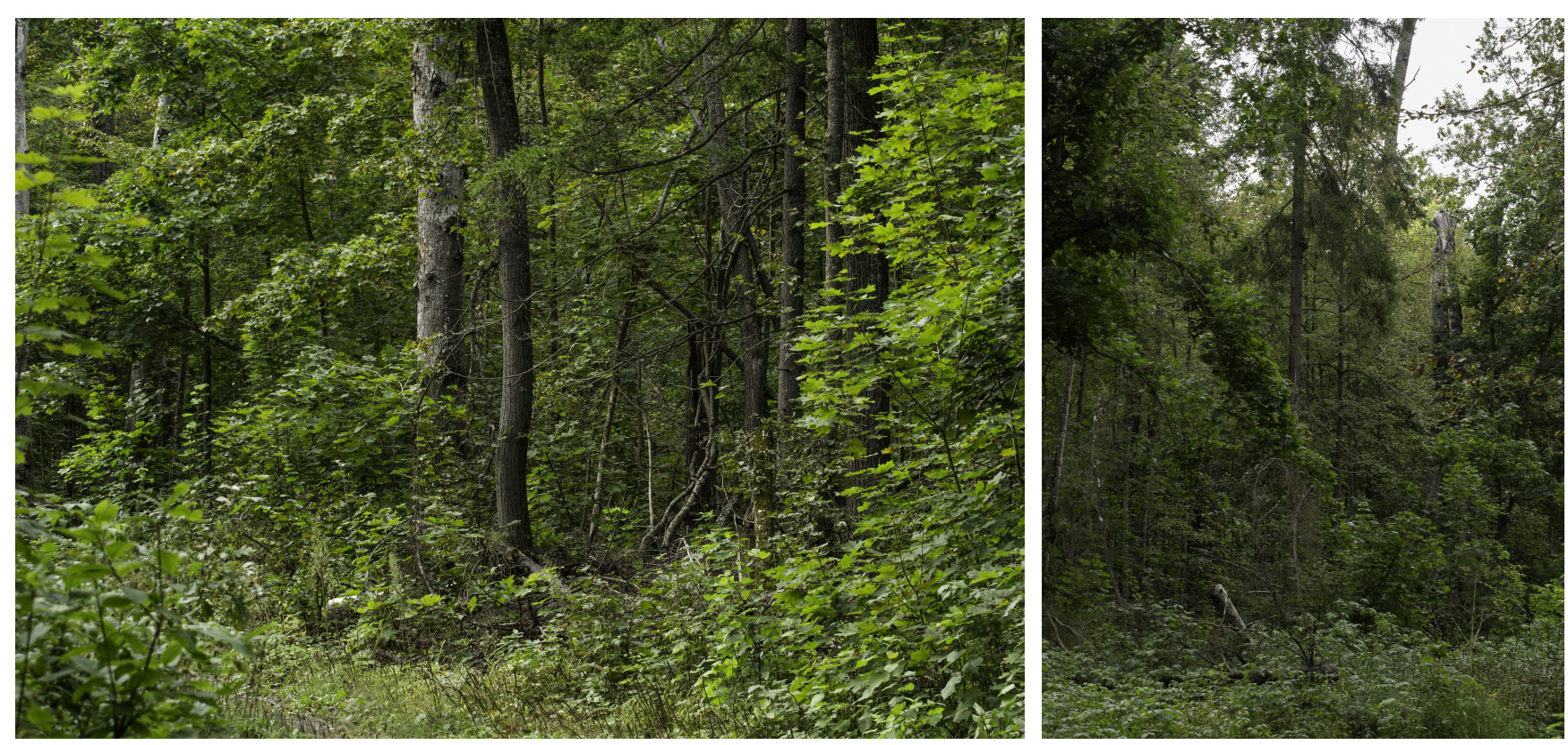

Fig. 2. Habitat of Clemmus troglodytes in the Mordovia State Nature Reserve (photo: Stanislav V. Gubin). 
Among mycophagous handsome fungus beetles, members of Anamorphidae are probably obligate spore feeders both as larvae and adults. As an adaptation to sporophagy adults have mandibles composed of a well-developed mola, brushy prostheca and bifid apical incisor lobe, and the known larvae of Anamorphidae (e. g., Mychothenus Strohecker, Anagaricophilus Arrow) have the incisor lobe reduced or absent (Tomaszewska, 2010).

\section{Acknowledgements}

The authors are grateful to N.B. Nikitsky (the Zoological Museum of Moscow State University, Moscow) for the information on the Clemmus specimen from Yaroslavl, to S.A. Belokobylsky (ZIN, St. Petersburg), E.A. Ivanov (Cheboksary) and L.Yu. Majorova (St. Petersburg) for assistance in the transfer of entomological material, to G.B. Semishin (Saransk) for his help during the field studies in the Mordovia State Nature Reserve, to S.V. Gubin for the photos of biotopes and to A.V. Kovalev (All-Russian Institute of Plant Protection, St. Petersburg, Pushkin), and Ya.N. Kovalenko (All-Russian Plant Quarantine Center, Moscow region, Ramensky district, Bykovo) for information support. Two anonymous reviewers are acknowledged for their helpful comments and corrections.

\section{References}

Chugunov G.G., Vargot E.V., Khapugin A.A. 2017. Materials to the flora of the Mordovia State Nature Reserve (Report 3). Proceedings of the Mordovia State Nature Reserve 19: 220-228. [In Russian]

Egorov L.V., Semishin G.B. 2016. The coleopterans collected using window traps in the Mordovia State Nature Reserve. Report 1. Proceedings of the Mordovia State Nature Reserve 17: 70-78. [In Russian]
Gribova S.A., Isachenko T.I., Lavrenko E.M. (Eds.). 1980. Vegetation of the European Part of the USSR. Leningrad: Nauka. 429 p. [In Russian]

Heijerman T., Noordijk J. 2017. Monochamus-monitoring 2016. populatieonderzoek in de Schoorlse Duinen en bij Nuenen. Rapport EIS kenniscentrum Insecten. Leiden. 24 p.

Kovalenko Ya.N., Nikitsky N.B. 2013. New to Russia and interesting finds of xylophilous beetles (Coleoptera) in the middle Russian forest-steppe zone. Bulletin of Moscow Society of Naturalists. 118(2): 20-26. [In Russian]

Mateleshko A.Yu. 2009. The new and little-known species of beetles (Insecta, Coleoptera) in Ukrainian Carpathians fauna. Vestnik zoologii 43(2): 179-183. [In Ukrainian]

Robertson J., Ślipiński A., Moulton M., Shockley F.W., Giorgi A., Lord N.P., McKenna D.D., Tomaszewska W., Forrester J., Miller K.B., Whiting M.F., McHugh J.V. 2015. Phylogeny and classification of Cucujoidea and the recognition of a new superfamily Coccinelloidea (Coleoptera: Cucujiformia). Systematic Entomology 40: 745-778. DOI: $10.1111 /$ syen. 12138

Roubal J. 1936. Katalog Coleopter (broukü) Slovenska a Podkarpatska. Praha. Vol. 2. 434 p.

Shockley W.F., Tomaszewska K.W., Mchugh J.V. 2009. An annotated checklist of the handsome fungus beetles of the world (Coleoptera: Cucujoidea: Endomychidae). Zootaxa 1999: 1-113.

Tomaszewska K.W. 2000. Morphology, phylogeny and classification of adult Endomychidae (Coleoptera: Cucujoidea). Annales Zoologici 50: 449-558.

Tomaszewska K.W. 2007. Family Endomychidae Leach, 1815. In: I. Löbl, A. Smetana (Eds.): Catalogue of Palaearctic Coleoptera. Vol. 4. Stenstrup: Apollo Books. P. 559-568.

Tomaszewska K.W. 2010. Endomychidae Leach, 1815. In: R.A.B. Leschen, R.G. Beutel, J.F. Lawrence (Eds.): Handbook of Zoology, Volume 2. Coleoptera. Berlin; New York: Walter de Gruyter GmbH \& Co. P. 442-454.

\title{
ПЕРВАЯ НАХОДКА CLEMMUS TROGLODYTES (COLEOPTERA: COCCINELLOIDEA, ANAMORPНIDAE) ДЛЯ ФАУНЫ РОССИИ
}

\author{
В. Томашевска ${ }^{1}$, Л. В. Егоров ${ }^{2,3}$, А. Б. Ручин ${ }^{3}$, Д. В. Власов ${ }^{4}$ \\ ${ }^{1}$ Музей и Институт зоологии Польской академии наук, Польша \\ e-mail:wiolkat@miiz.waw.pl \\ ${ }^{2}$ Государственный природный заповедник «Присурский», Россия \\ e-mail:platyscelis@mail.ru \\ ${ }^{3}$ Объединенная дирекиия Мордовского государственного природного заповедника имени П.Г. Смидовича \\ и национального парка «Смольный», Россия \\ e-mail: sasha_ruchin@rambler.ru \\ ${ }^{4}$ Ярославский государственный историко-архитектурный музей-заповедник, Россия \\ e-mail:mitrich-koroed@mail.ru
}

\begin{abstract}
В результате исследований 2017 г. в Мордовском заповеднике (Республика Мордовия, Россия) был обнаружен Clemmus troglodytes. Ранее C. troglodytes был собран в г. Ярославль (Ярославская область, Россия). В настоящей работе мы впервые сообщаем о нахождении рода Clemmus и вида C. troglodytes для фауны России. Эти находки заметно расширяют ареал вида к северу и востоку.
\end{abstract}

Ключевые слова: Anamorphidae, Coleoptera, Coccinelloidea, жуки-плеснееды, Мордовия, Мордовский государственный природный заповедник, находки, Россия, Ярославская область 